\title{
学習者の学習方略使用に対寸る有効性とコストの認知は 個別学習支援で変容するか
}

\author{
——算数問題解決における学習者の方略使用に関する有効性とコストの認知 (2) — \\ ○柏原志保 ${ }^{1}$ ・ 小澤郁美 ${ }^{1,2}$ ・福屋いずみ ${ }^{1} \cdot$ 岡 直樹 $^{1}$ \\ $\left({ }^{1}\right.$ 広島大学大学院教育学研究科 $\cdot{ }^{2}$ 日本学術振興会 $)$ \\ キーワード : 学習方略, 学習者の認知, 認知カウンセリング
}

\begin{abstract}
The effects of cognitive counseling on learners' cognition: The improvement of the perceived usefulness and cost for using diagram Shiho KASHIHARA ${ }^{1}$, Ikumi OZAWA ${ }^{1}$, Izumi FUKUYA ${ }^{1}$ and Naoki OKA ${ }^{1}$ ( ${ }^{1}$ Graduate School of Education, Hiroshima Univ., ${ }^{2}$ Japan Society for the Promotion of Science)

Key Words: learning strategy, learners' cognition, cognitive counseling
\end{abstract}

\section{目 的}

効果的な学習には, 適切な学習方略の習得が重要である。 例えば，外的資源を活用する方略 (e.g., 図表活用方略) が算 数文章題解決に有効であることが示されている (植阪, 2009) その一方で，実践場面では，学習者は専門家が有効だと考え る学習方略を必ずしも自発的に使用しないことが報告されて いる (e.g., 市川, 1998)。この問題には, 適切な学習方略の自 発的使用には学習者が方略に対して抱く有効性やコストの認 知が関わっていることが示唆されている (植阪, 2014)。その ため, 学習支援を行う際は, 学習者の認知を把握し, 適切な 学習方略の使用を促す支援が求められる。そしてその効果は, 適切な学習方略の使用の有無という行動面の変容と, 学習者 が方略に対して抱く認知の変容から考える必要がある。

そこで本研究では, 学習者の認知の変容に着目し, 認知力 ウンセリングによる小学生への個別学習支援が学習者の認知 に及ぼす影響を検討する。認知カウンセリングとは, 認知的 な問題を抱える学習者に対し，個別面接等を通してつまずき の原因を探り，解決のための支援を行う実践的研究活動であ る(市川, 1998)。本研究では, 特に図表活用方略を取り上げ, 算数の認知カウンセリングの支援前後における学習者の方略 使用に対する有効性およびコストの認知の変容を検討した。

\section{方 法}

調査対象者 $\mathrm{A}$ 大学で開講される学習支援活動に参加した 小学 4-6 年生 26 名。当該活動では, 近隣地域の小学 4-6 年生 を対象に, 毎週 1 回 1 時間程度, 約 10 回にわたり認知カウン セリングによる算数の学習支援を行っている。活動の期間は およそ 4 ケ月であり, 活動の参加者は年 2 回の募集に応募し た児童の中から抽選で決定される。本研究では, 20XX 年 58 月または $20 X X$ 年 11 月-翌年 2 月のいずれかの期間に初め て当該活動に参加し認知カウンセリングを受けた児童を調査 の対象とした。

要因計画 3 (学習者の認知 : 有効性, 実行コスト, 心理コ スト $) \times 2$ (調査時期 : 事前, 事後) の 2 要因参加者内計画。

調查用紙 植阪 (2014) の図表活用方略に対する有効性の 認知を測定する 3 項目 (e.g., 「図は算数の文章題をうまくとく ために役立つと思いますか？」) と，植阪 (2014) を元に作成 した学習者のコストの認知を尋㸚るコスト感尺度で構成した。 コスト感尺度は, 方略の実行にかかるコスト (実行コスト, 11 項目 : e.g., 「図をかくことは, 手間がかかると思います か?」) と, 心理的なコスト (心理コスト, 9 項目 : e.g., 「図 をかくのは気分がのらないですか?」) の 2 因子構造であっ た。各項目について, 5 件法 (1：まったくそう思わない-5： とてもそう思う) で回答を求めた。
手続き 認知カウンセリングの支援開始前および全 10 回 の支援終了後に，同一の質問紙調査を実施した。

\section{結果と考察}

事前または事後調査で，半数以上の項目が無回答であった 回答者 2 名を除外し，24 名を分析対象とした。逆転項目を処 理し, 得点が高いほど有効性またはコストの認知が高いこと を意味するように得点処理を加えた。欠損值は平均值代入に より補完した。Figure 1 に, 支援の前後における有効性とコス トの認知 (実行コスト，心理コスト) の平均值を示す。

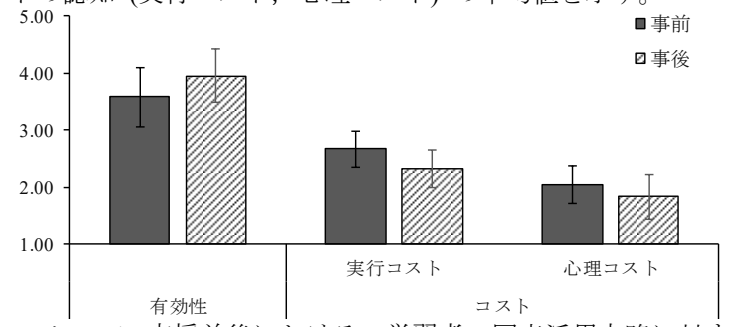

Figure 1. 支援前後における，学習者の図表活用方略に対す る有効性, コストの認知の変化 (エラーバーは $95 \%$ 信頼区間)

2 要因分散分析の結果, 学習者の認知の主効果 $(F(1,23)=$ $\left.47.26, p<.001, \eta_{\mathrm{p}}{ }^{2}=.67\right)$, 学習者の認知と調查時期の交互作用 $\left(F(1.28,29.39)=3.86, \varepsilon=.64, p<.05, \eta_{\mathrm{p}}^{2}=.14\right)$ が有意であ った。コスト感に関して, 実行コストのみが事前調査よりも 事後調查で有意に低減した $\left(F(1,23)=4.45, p<.05, \eta_{\mathrm{p}}{ }^{2}=.16\right)$ 。 また，調查時期に関わらず，心理コストよりも実行コストの 方が有意に高かった $(F(1.21,27.90)=21.64, \varepsilon=.61, p<.001$, $\left.\eta_{\mathrm{p}}{ }^{2}=.48 ; F(1.26,29.09)=43.14, \varepsilon=.63, p<.001, \eta_{\mathrm{p}}{ }^{2}=.65\right) 。$

本調査から，認知カウンセリングによる支援の前後で，図 表活用方略に対する学習者の実行コストが低減することが示 唆された。今後, 実行にかかるコストと心理的なコストを弁 別した上で, 行動面の变容の検討を行っていく必要がある。

\section{引用文献}

市川 伸一 (編) (1998). 認知カウンセリングから見た学習の 相談と指導 ブレーン出版

植阪 友理 (2009). 認知カウンセリングによる学習スキルの 支援とその展開一一図表活用方略に着目して一一認知 科学, 16, 313-332.

植阪 友理 (2014). 数学的問題解決における図表活用の支援 数学的問題解決における図表活用の支援——理論と実践 を結ぶ「REAL アプローチ」の展開——風間書房 